\title{
Marketing Communication Tools in Food Industry: A Case Study on Cukurova Region in Turkey
}

\begin{abstract}
Nermin Bahşi ${ }^{1, a, *}$, Dilek Bostan Budak ${ }^{2, b}$
${ }^{1}$ Department of Organic Farming Management, Kadirli School of Applied Sciences, Osmaniye Korkut Ata University, 80760 Osmaniye, Turkey ${ }^{2}$ Department of Agricultural Economics, Faculty of Agriculture, Çukurova University, 01330 Adana, Turkey *Corresponding author

A R T I C L E I N F O A B S T R A C T

Research Article

Received : 30/12/2019 Accepted : 05/02/2020

Keywords:

Marketing communication

Communication tools

Consumer behaviour

Food products

Çukurova Region

In this study, it is aimed to examine which level marketing communicating tools are used in the food industry in Çukurova Region, Turkey. For this purpose, a survey was applied to 92 enterprises which process milk and dairy products, meat and meat products, fruit juice industry in both Adana and Mersin. Also, face to face interview was conducted to gather data from 400 consumers who were determined via simple random sampling, living in Adana province. It was found out that enterprises used the marketing communication tools (sales promotion, advertisement etc.) to increase sales and reduce inventory, even if they are not mostly aware of the concept of marketing communications. They also indicated that they do not practice marketing communication programs at all. The most used tools by the enterprises are personal sales, direct marketing, sales promotions and advertisement. Also, as a result of correlation analysis showed that there is an effect between the enterprises' use of marketing communication tools and brand and market performance. Consumers stated that the sales promotions are the most effective marketing communication tools on their preferences not only buying food products but also changing the brands. Consumers mostly decide what to buy and which brand while they are in the market. In this case, advertisement, promotion and to the content of the product were the most important factors regarding consumers' choices. It was found out that consumers' gender, age, education and income levels were also effective on their preferences on buying different food products. Consumers attitude was different about marketing communication tools; such as young people mostly affected by media and primary and secondary school graduates mostly influenced by additional gifts provided free of charge with the main product.
\end{abstract}

nerminbahsi@osmaniye.edu.tr

https://orcid.org/0000-0003-1630-7720

b@dbostanbudak@gmail.com

(iD https://orcid.org/0000-0001-6318-698X

\section{Introduction}

The economic and technological developments in the world create an intense competition environment on marketing. Along with being primarily marketing, business developments, consumers, purchasing behaviours of consumers have also changed. Today's changing customer profile emphasizes the need to integrate information and communication technologies of businesses into sales and marketing approaches and strategies (Babacan et al., 2008). The intense competition in the markets makes communication for businesses an important market power and consumers have to make changes in their marketing strategies when consumers choose their own brands among goods and services that do not have very different characteristics compared to competitors. According to Mihart (2012), the survival and development of businesses in a competitive economic system requires accurate and detailed information about customer behaviour along with his motivation, attitudes and behaviours. Modern marketing concept is an approach that keeps consumers needs and wants in the foreground and also includes consumer satisfaction. To be able to better analyse consumer wants and needs, to present appropriate products and services, to distribute them appropriately, to meet consumers' demand when requested, to inform consumers about the existence and benefits of goods and services and to provide after sales services, as well as to meet consumer satisfaction and contentment, the need for "marketing communication" is inevitable (Uçak, 2004)

Marketing communication is the process of getting messages from the market, explaining and moving in the direction of the target with the intention of awakening the desired response, providing the integrated stimuli, changing the existing business messages and creating new communication opportunities through the established communication channels (Durmaz, 2001; Uçak, 2004, Ebren, 2006). Marketing communication is the means by 
which enterprises directly or indirectly attempt to inform, convince and remind consumers about the products or brands they sell (Keller, 2001; Keller, 2009) In a sense, marketing communication represents the "voice" of companies and brands, and is a means of establishing dialogue and establishing relationships with consumers (Keller, 2009). It is the consistency of the messages sent by the various channels of precursor communication of effective marketing communications (Zavrsnik and Jerman, 2011). In order to facilitate the process of informing, reminding and persuading by establishing an effective communication between the business and the consumers, the marketing communication provides the communicating of the messages to the consumers through the product, price, distribution and maintenance mix members.

In a cluttered, complicated market, marketing communications can allow brands to attract attention and help consumers without appreciating comparative advantages (Keller, 2001). Marketing communication; (Uçak, 2004; Durmaz, 2001; Ebren, 2006; Tuğrul, 2009) aims to inform the target consumers about the product or service, to strengthen their attitudes and behaviours in the desired direction and vice versa or to create a new attitude and behaviour aimed at them. It is desired that the messages communicated through marketing communication will remain as information in the mind of the consumer and thus affect the future purchasing decision (Odabaşı and Oyman, 2012; Uçak, 2004). Effective marketing communication contributes to brand awareness and positive image formation (Erpelit, 2010). Effective marketing communication programs designed and implemented are invaluable for building and managing brand value (Keller, 2001). Marketing communication tools are considered as advertising, sales promotions, public relations, direct marketing and personal sales (Jerman and Zarvrsnik, 2013). Therefore, these elements indicate the promotion of marketing mix members. Marketing communication; specific promotional functions but also covers all the actions and components of the marketing in scope. (Özgül, 2008). When marketing communication tools are used individually, it is stated that if they are strategically coordinated, the effect they will create will be greater (Anantachart, 2004).

Economic and technological developments affect the purchasing behaviour of consumers along with their lifestyles. Consumers are having a hard time to choose between products and brands in the markets as their numbers are increasing and diversifying every day. In agricultural products, like others, various new brands are emerging to compete in market. In order to influence the consumer to buy more and re-purchase the product, creation of brand awareness in the consumer's mind is important. Regarding consumers' preferences among different brands, the importance of marketing communication arises and businesses need to use these tools effectively.

In this study, it was aimed to investigate how and to what extend the marketing communication tools are used by the food enterprises, how they affect the performance of the enterprises and also to show the effects of the marketing communication tools on the purchasing behaviour of the consumers.

\section{Materials and Methods}

The primary data of the study consists of the data gathered through survey applied on the food enterprises registered in the Adana and Mersin Provincial Directorate of Food, Agriculture and Animal Husbandry in order to investigate the marketing communication tools used by the enterprises producing the processed agricultural products and to what extend their expectations are met by these tools. Additionally, data consists of survey results gathered from consumers living in urban part of Adana, conducted to measure the effect of marketing communication tools on consumers' purchasing decision process. In addition, the study was supplemented by secondary data. There are 334 businesses registered in the Adana and Mersin Provincial Food, Agriculture and Livestock Directorate (GTHB. 2014), active on producing meat and meat products, milk and dairy products, fruit juice (soft drink). 92 questionnaires were evaluated in the survey. The representative sample of this population for the consumer survey conducted with the purpose of studying consumer behaviours in terms of preference of agriculture based industrial products was determined by the method of "Simple Random Probability Sampling Based on Ankerite Rates". In this study, 95\% confidence interval and sample volume of $5 \%$ error were calculated as 384 . The number of the questionnaire was completed to 400, thinking it might be wrong or incomplete. Questionnaires made in accordance with the objectives of the research were obtained and the resulting data were entered into prepared databases and prepared for analysis. Different statistical analyses were applied according to the purpose of the study.

\section{Results and Discussion}

In the scope of the research, the issue has been dealt with in terms of both producers and consumers. While the enterprises are examined, both the general situation of the relevant markets and enterprises that make up these markets, and enterprises characteristics need to be examined. The features of the reviewed enterprises are important for getting an idea of the main mass and for understanding the behaviour of the business. For this reason, enterprise characteristics were examined before reviewing the use of businesses marketing communications tools.

When the enterprises are examined, both the general situation of the relevant markets as well as the enterprises that make up these markets and their characteristics need to be examined. The features of the inspecting enterprises are important for getting an idea of the main group and for understanding the behaviour of the business. For this reason, business features have been reviewed before businesses use marketing communication tools.

When the distribution of the enterprises participating in the survey according to the activity subjects is examined; $50 \%$ of the enterprises operate in milk and dairy products, $29.35 \%$ in meat and meat products and $20.65 \%$ in fruit juice (beverage) sector. The average operating period of the enterprises is 20 years. Regarding the level of marketing activities of the enterprises, $45.66 \%$ were active at the local level while $34.78 \%$ were active at the regional level. When the classification of business size groups is 
taken into consideration according to KOSGEB employee numbers; (61.96\%) enterprises with less than 10 employees. When businesses are asked to rate their current market position in terms of the region they operate in, (milk and dairy products $58.70 \%$, meat and meat products $40.74 \%$ and fruit juice $42.11 \%$ ). Only $10.87 \%$ of businesses that declare themselves as market leaders. The primary objective of $39.96 \%$ of enterprises is to maintain their current position. While it is stated that promoting products and services is important for small businesses $(83.70 \%)$, it is stated that promotion of market share / sales $(36.1 \%)$ is the most important reason. Odunlami and Ofoegbu (2011) indicate that promotion will help raise awareness, stimulate and increase demand, encourage product testing, set expectations, protect loyal customers, fight against competitive promotional efforts, and reduce sales volatility.

It is seen that interviewed businesses are not aware of large marketing communication concept (79.35\%) and not applied in business (84.78\%). It is influenced by the fact that interviewed people are in high school and other education levels and the awareness of the fact that the businesses are at micro level and the rate of implementation in the enterprises is low. Fruit juice enterprises are the ones that implement the most in marketing communications programs. Mainly, marketing communications programs are seen to be implemented more in medium-sized enterprises.

Developed by Duncan and Moriarty (1998) and organized by Reid (2005), the IMC (Integrated Marketing Communication) performance structure and the scale of the items were used to measure the performance of the firms Integrated Marketing Communications. The Integrated Marketing Communication scale was handled by Reid (2005) in five dimensions as "Interaction, Organizational Infrastructure, Marketing Mission, Strategic Consistency, Planning and Evaluation". This scale was applied only to businesses that said that they applied the marketing communication program and was evaluated for 14 businesses (Table 1). As you can see from the chart, these five dimensions are important for businesses.

Although the vast majority of companies stated that they were unaware of the concept of marketing communication, it has been found out that many of them were using at least one marketing communication tool (MCT) when they needed (Table 2). The most widely used MCT by companies were direct selling, sales promotion, personal selling and ads. Fairs and sponsorship were the MCTs uncommon in these companies. Esposito (2013), in their studies in Italy, notes that the communication tools most frequently used by SMEs are participate in fairs, sponsorships and activities and are the most emerging tools for online communication, despite the use of traditional advertising.

The tools used for advertising can have different effects on consumers. The most commonly used tools for advertising by businesses are billboard and radio. The widespread use of these tools is due to the fact that largescale costs are lower than other tools. Esposito (2013) states that television is considered to be expensive and not very effective in achieving specific goals. It is also seen that television is not a widely used tool for commercials and that businesses do not want to allocate too much of their budget for advertising. Public Relations has the potential to build a corporate image, such as advertising and beyond, to establish a personal relationship with customers, and to grow among stakeholders, such as employees, communities, a brand or a company (Anantachart, 2004). Public relations are used by some businesses occasionally (20.65\%) even though they are not used by the vast majority of the businesses interviewed $(68.48 \%)$. Business activities carried out within the scope of public relations activities; Sponsorship for local activities, strengthening of employees (Education, social activities etc.), Supporting social events, Contribution to charity (moderate), Sales of safe products sensitive to environment (at high level). It seems that the most used sales promotional tools are discounts, other tools such as sales quotas, advantageous packages and free trials. Because the surveyed enterprises are largely composed of micro and small businesses, marketing communication tools are either never or rarely used. Information on marketing communications budget was not intended to be provide by businesses, but they stated that these budgets were very few.

The Kruskal-Wallis $\mathrm{H}$ test was conducted to investigate whether there is any difference in the communication tools used depending on the operating area and size of the enterprise. (Regarding the field of activity:

$\mathrm{X}_{(\text {calculated })}=0.413<\mathrm{X}_{(\text {table })}=5.99(\mathrm{P}=0.813>0.05)$; in relation to business size: $\mathrm{X}^{2}$ (calculated) $=2.870<\mathrm{X}^{2}{ }_{\text {(table })}=5.99$ $(\mathrm{P}=0.238>0.05))$.

According to the results of the Kruskal Wallis H Test, there is no statistically significant difference between the marketing communication tools used by the different fields of activity and enterprises of different sizes. In other words, the marketing communications tools that businesses use do not depend on their business areas and business sizes.

The purpose of the marketing communication is to ensure trial their by informing the target audience about goods or services (İçli, 2010). Companies mainly used marketing communication tools to remind products (44.57\%); to introduce new product $(22.83 \%)$; and to maintain their position $(13.04 \%)$; and to increase their sales, image renewal, stock reduction. The field on which the use of marketing communication tools is most beneficial is considered as increasing sales.

In order to measure brand performance, scale, prepared by Reid (2005), was used in the study which consists of three dimensions; performance related to sales, brand advantage, customer satisfaction. In general, enterprises assessed their level as intermediate in terms of brand performance. Generally, the companies evaluate themselves moderately in terms of sales-related performance, brand advantage and customer satisfaction (Table 3).

In the similar studies (Ebren, 2006; Reid, 2005; Çalık et al., 2013), the relationship between IMC performance with brand performance and business performance results was investigated and the effect of IMC on firm performance was investigated. However, in our study, businesses were generally at the micro scale and they are not aware of the marketing communication concept. Thus, it resulted in a small number of businesses responding to 
the IMC performance scale. Therefore, it was not possible to apply a similar assessment. Instead, the relationship between the use of marketing communication tools and the brand performance structure and business performance was explored in order to establish similar relationships. Rather, the relationship between the use of marketing communication tools and brand performance structure and business performance were investigated in order to reveal the similarities and effects of marketing communication tools usage on brand and business performance were tried to be revealed. Correlation Analysis conducted in order to investigate whether a relationship between brand performance evaluation with marketing communication tools used. But Spearman were calculated because data was not normally distributed in terms of communication tools variables. Spearman correlation coefficient was found 0.252 and $\mathrm{P}=0.015$ which was lower than 0.05 that appears to be a linear relationship in a positive direction between brand performance evaluation with marketing communication tools used by companies. If the use of marketing communications tools is increased, also brand performance evaluation is also increased as a certain extent.

When we look at the use of marketing communication tools at the level of brand performance dimensions, sales performance and brand advantage of businesses increase as the use of advertising, public relations, sales promotions and sponsorship activities increases (Table 4). Public Relations and Fair etc. As tools usage increases, the level of customer satisfaction increases.

Company performance is generally used to express the achievements and the situations that arise as a result of the path to achieve certain objectives, depending on the environmental characteristics of the enterprises within a certain period of time (Çalık et al., 2013). Changes in the specific topics of the last three years in order to measure the operating performance of the company were asked to evaluate. According to these assessments; companies stated that of the companies, $52.17 \%$ increased their market share, $56.52 \%$ increased of awareness gain on the market, $58.70 \%$ increased to acquire of new customers, $51.09 \%$ increased the consumer retention success and $51.09 \%$ of the companies emphasized that their communication budget remained unchanged. Correlation analysis was performed to see whether there was a relationship between business performance with the use of marketing communications tools and whether there was an impact of brand performance on the market performance (Table 5 and Table 6). Results indicates a positive linear relationship between the variables in both cases. This relationship shows that increasing use of marketing communication tools of company increased of business performance and increasing the brand performance increased market performance.

Reid et al. (2001) suggests that a strong positive relationship exist between self-reported performance indicators and the level of integrated marketing and communication obtained from participants, and that performance in terms of profitability performed well in terms of profitability relative to participants, market share, sales growth and competitor firms. Korkut et al. (2005) found that integrated marketing communications components have a positive effect on company performance and brand value when they were working on businesses operating in the beverage industry in Thrace.

Correlation Analysis was performed to see the relation between the operational performance elements and the marketing communication tools used (Table 7). This relationship showed that increasing use of marketing communication tools of company increased business performance and increasing brand performance also increased market performance. This relationship shows that increasing use of advertising, public relations, sales promotion and sponsorship activities of company increased market share and profitability (sales revenue); that increasing use of advertising, public relations, sales promotion, sponsorship, fairs and so on. of company increased the level of awareness on the market; that increasing use of advertising, public relations, and sponsorship activities had increased achievement of new consumers; that increasing use of public relations, sales promotions, sponsorships, fairs and so on. tools increased the success of holding the consumer.

Table 1. IMC performance structure dimensions

\begin{tabular}{l|ccc}
\hline & $\mathrm{N}$ & Average & Standard deviation \\
\hline Interaction & 14 & 3.63 & 1.01 \\
Marketing Mission & 14 & 3.86 & 1.09 \\
Organizational Infrastructure & 14 & 3.45 & 0.98 \\
Strategic Consistency & 14 & 3.69 & 1.02 \\
Planning and Evaluation & 14 & 3.69 & 0.84 \\
\hline
\end{tabular}

Table 2. Frequency of using marketing communication tools

\begin{tabular}{l|cccccccc}
\hline \multirow{2}{*}{ Marketing Communication Tools } & \multicolumn{3}{|c}{ Never } & \multicolumn{2}{c}{ Sometimes } & \multicolumn{2}{c}{ Always } & \multicolumn{2}{c}{ Total } \\
\cline { 2 - 9 } & $\mathrm{f}$ & $\%$ & $\mathrm{f}$ & $\%$ & $\mathrm{f}$ & $\%$ & $\mathrm{f}$ & $\%$ \\
\hline Advertising & 44 & 47.83 & 28 & 30.43 & 20 & 21.74 & 92 & 100.00 \\
Public relations & 63 & 68.48 & 19 & 20.65 & 10 & 10.87 & 92 & 100.00 \\
Sales promotion & 27 & 29.35 & 49 & 53.26 & 16 & 17.39 & 92 & 100.00 \\
Direct selling & 17 & 18.48 & 10 & 10.87 & 65 & 70.65 & 92 & 100.00 \\
Sponsorship & 66 & 71.74 & 21 & 22.83 & 5 & 5.43 & 92 & 100.00 \\
Personal selling & 28 & 30.43 & 13 & 14.13 & 51 & 55.43 & 92 & 100.00 \\
Other & 87 & 94.57 & 3 & 3.26 & 2 & 2.17 & 92 & 100.00 \\
\hline
\end{tabular}


Table 3. Brand performance structure dimensions

Brand performance structure dimensions

Sales-related performance

Brand advantage

$\mathrm{N} \quad$ Mean

2.04

Standard deviation

$92 \quad 2.04 \quad 0.67$

Customer satisfaction

$92 \quad 2.06$

0.67

92

2.36

0.72

Table 4. Brand performance dimensions and marketing communication tools correlation analysis

\begin{tabular}{|c|c|c|c|c|c|c|c|c|}
\hline & & Adv. & $\begin{array}{l}\text { Public } \\
\text { relations }\end{array}$ & $\begin{array}{c}\text { Sales } \\
\text { promotions }\end{array}$ & $\begin{array}{l}\text { Direct } \\
\text { selling }\end{array}$ & Sponsorship & $\begin{array}{l}\text { Personal } \\
\text { selling }\end{array}$ & Other \\
\hline \multirow{3}{*}{$\begin{array}{l}\text { Sales } \\
\text { performance }\end{array}$} & $\mathrm{CC}$ & $0.283^{* *}$ & $0.328 * *$ & $0.329 * *$ & -0.034 & $0.373 * *$ & -0.119 & 0.122 \\
\hline & Sig. (2-tailed) & 0.006 & 0.001 & 0.001 & 0.748 & 0 & 0.26 & 0.245 \\
\hline & $\mathrm{N}$ & 92 & 92 & 92 & 92 & 92 & 92 & 92 \\
\hline \multirow{3}{*}{$\begin{array}{l}\text { Brand } \\
\text { advantage }\end{array}$} & $\mathrm{CC}$ & $0.354 * *$ & $0.285 * *$ & $0.260^{*}$ & 0.054 & $0.340 * *$ & -0.194 & 0.158 \\
\hline & Sig. (2-tailed) & 0.001 & 0.006 & 0.012 & 0.612 & 0.001 & 0.064 & 0.133 \\
\hline & $\mathrm{N}$ & 92 & 92 & 92 & 92 & 92 & 92 & 92 \\
\hline \multirow{3}{*}{$\begin{array}{l}\text { Customer } \\
\text { satisfaction }\end{array}$} & $\mathrm{CC}$ & 0.18 & $0.250 *$ & 0.15 & 0.067 & 0.167 & -0.041 & $0.239 *$ \\
\hline & Sig. (2-tailed) & 0.086 & 0.016 & 0.153 & 0.524 & 0.111 & 0.695 & 0.022 \\
\hline & $\mathrm{N}$ & 92 & 92 & 92 & 92 & 92 & 92 & 92 \\
\hline
\end{tabular}

CC: Correlation Coefficient, **. Correlation is significant at the 0.01 level (2-tailed), *. Correlation is significant at the 0.05 level (2-tailed).

Table 5. Relationship between use of marketing communication tools and business performance

\begin{tabular}{l|ccc}
\hline & \multicolumn{2}{c}{ Business Performance } \\
\hline \multirow{3}{*}{ Spearman's rho } & Marketing Communication Tools & Correlation Coefficient & $0.06^{* *}$ \\
& & Sig. (2-tailed) & 0.003 \\
& $\mathrm{~N}$ & 92 \\
\hline
\end{tabular}

**. Correlation is significant at the 0.01 level (2-tailed).

Table 6. Relationship between brand performance and market performance

\begin{tabular}{c|cc}
\hline & & Market Performance \\
\hline \multirow{3}{*}{ Brand performance } & Pearson Correlation & $0.550^{* *}$ \\
& Sig. (2-tailed) & 0.000 \\
& $\mathrm{~N}$ & 92 \\
\hline
\end{tabular}

Table 7. Relationship between business performance and use of marketing communication tools

\begin{tabular}{|c|c|c|c|c|c|c|c|c|}
\hline & & Adv. & $\begin{array}{c}\text { Public } \\
\text { relations }\end{array}$ & $\begin{array}{c}\text { Sales } \\
\text { promotions }\end{array}$ & $\begin{array}{l}\text { Direct } \\
\text { selling }\end{array}$ & Sponsorship & $\begin{array}{l}\text { Personal } \\
\text { selling }\end{array}$ & Other \\
\hline \multirow{3}{*}{ Market share } & $\mathrm{CC}$ & $0.328 * *$ & $0.348 * *$ & $0.239 *$ & -0.06 & $0.306^{* *}$ & -0.168 & 0.14 \\
\hline & Sig. (2-tailed) & 0.001 & 0.001 & 0.022 & 0.571 & 0.003 & 0.11 & 0.184 \\
\hline & $\mathrm{N}$ & 92 & 92 & 92 & 92 & 92 & 92 & 92 \\
\hline \multirow{3}{*}{ Gain awareness in the market } & $\mathrm{CC}$ & $0.315 * *$ & $0.268 * *$ & $0.271 * *$ & 0.033 & $0.311 * *$ & -0.171 & $0.206^{*}$ \\
\hline & Sig. (2-tailed) & 0.002 & 0.01 & 0.009 & 0.755 & 0.003 & 0.104 & 0.048 \\
\hline & $\mathrm{N}$ & 92 & 92 & 92 & 92 & 92 & 92 & 92 \\
\hline \multirow{3}{*}{ Getting a new consumer } & $\mathrm{CC}$ & $0.300 * *$ & $0.238^{*}$ & 0.192 & 0.066 & $0.242 *$ & -0.158 & 0.198 \\
\hline & Sig. (2-tailed) & 0.004 & 0.022 & 0.067 & 0.529 & 0.02 & 0.133 & 0.058 \\
\hline & $\mathrm{N}$ & 92 & 92 & 92 & 92 & 92 & 92 & 92 \\
\hline \multirow{3}{*}{ Consumer retention success } & $\mathrm{CC}$ & 0.201 & $0.319 * *$ & $0.253 *$ & 0.078 & $0.245^{*}$ & 0.032 & $0.230 *$ \\
\hline & Sig. (2-tailed) & 0.055 & 0.002 & 0.015 & 0.458 & 0.019 & 0.765 & 0.027 \\
\hline & $\mathrm{N}$ & 92 & 92 & 92 & 92 & 92 & 92 & 92 \\
\hline \multirow{3}{*}{ Profitability (or sales revenue) } & $\mathrm{CC}$ & $0.393 * *$ & $0.328 * *$ & $0.376 * *$ & -0.106 & $0.310 * *$ & -0.015 & 0.076 \\
\hline & Sig. (2-tailed) & 0 & 0.001 & 0 & 0.313 & 0.003 & 0.884 & 0.469 \\
\hline & $\mathrm{N}$ & 92 & 92 & 92 & 92 & 92 & 92 & 92 \\
\hline \multirow{3}{*}{$\begin{array}{l}\text { Communication budget } \\
\text { (Adv., Sponsorship, etc.) }\end{array}$} & $\mathrm{CC}$ & 0.068 & -0.09 & -0.09 & 0.117 & 0.021 & -0.095 & 0.069 \\
\hline & Sig. (2-tailed) & 0.522 & 0.393 & 0.394 & 0.267 & 0.841 & 0.366 & 0.512 \\
\hline & $\mathrm{N}$ & 92 & 92 & 92 & 92 & 92 & 92 & 92 \\
\hline
\end{tabular}

CC: Correlation Coefficient **. Correlation is significant at the 0.01 level (2-tailed), *. Correlation is significant at the 0.05 level (2-tailed). 
Table 8 . The situation of purchasing products and changing the used brand by being affected by marketing communication tools

\begin{tabular}{|c|c|c|c|c|c|c|c|c|c|c|}
\hline & \multicolumn{2}{|c|}{ Adv. } & \multicolumn{2}{|c|}{ Discount } & \multicolumn{2}{|c|}{$\begin{array}{c}\text { Advantageous } \\
\text { package }\end{array}$} & \multicolumn{2}{|c|}{ Free trial } & \multicolumn{2}{|c|}{ Gifts } \\
\hline & $\mathrm{f}$ & $\%$ & $\mathrm{f}$ & $\%$ & $f$ & $\%$ & $f$ & $\%$ & $\mathrm{f}$ & $\%$ \\
\hline \multicolumn{11}{|c|}{ Purchasing Products by Being Affected by Marketing Communication Tools } \\
\hline Yes & 146 & 36.6 & 293 & 73.4 & 213 & 53.4 & 248 & 62.2 & 207 & 51.9 \\
\hline No & 187 & 46.9 & 62 & 15.5 & 106 & 26.6 & 83 & 20.8 & 95 & 23.8 \\
\hline Sometimes & 66 & 16.5 & 44 & 11 & 80 & 20.1 & 68 & 17 & 97 & 24.3 \\
\hline \multicolumn{11}{|c|}{ Changing the Used Brand by Being Affected by Marketing Communication Tools } \\
\hline$\overline{\text { Yes }}$ & 116 & 29.1 & 243 & 60.9 & 195 & 48.9 & 213 & 53.4 & 170 & 42.6 \\
\hline No & 208 & 52.1 & 85 & 21.3 & 125 & 31.3 & 100 & 25.1 & 129 & 32.3 \\
\hline Sometimes & 75 & 18.8 & 71 & 17.8 & 79 & 19.8 & 86 & 21.6 & 100 & 25.1 \\
\hline
\end{tabular}

Businesses are required to evaluate the degree of impact of marketing communications when firm sales are at a profitable level. Consistency of advertising messages (TV, radio, print, web, etc.) (1.67), database creation and individual marketing (2.01), Retention activities (coupons, discounts, prizes) Consumer relations (1.84), Customer relations (2.38), Collective contribution of the brand / Sensitivity to environment (2.32), Consumer attitudes and behaviours The effect of distribution channels (2.15) is moderate.

Multifactor analysis of variance was performed to investigate whether the companies showed a significant difference according to field of activity of business, company size and the type of company of brand performance, market performance and communication tools profitability impact assessments. When the data were analysed, it was found that companies did not show a significant difference according to the business scope of the brand performance, market performance, communication tools profitability impact assessments $(\mathrm{P}>0.05)$. In contrast, it was observed that no significant difference between the company size with market performance and communication tools profitability impact assessments profitability, which showed a significant difference between company size and brand performance $(\mathrm{P}<0.05)$. In addition, it is observed that there was no significant difference between types of companies with brand performance and market performance, which showed a significant difference between company type with communication tools profitability impact assessments profitability $(\mathrm{P}<0.05)$. The findings obtained from this study support the literature and show that there is a relationship between firm size and brand performance and company type and profitability impact evaluations. Also, as the use of marketing communication tools increases, the performance indicators also increase.

While analysing the consumer market, it is necessary that the structural characteristics of the market as a whole, as well as consumers and their behavioural characteristics that form the market are handled and explained separately. These are demographic characteristics, economic characteristics and consumer behaviour characteristics (Mutlu, 2007). Presenting the demographic and economic characteristics of the consumer group under review are needed to get an idea of the main mass and to understand consumer behaviour. For this reason, the demographic and economic characteristics of the households interviewed before the behaviour of the consumers regarding the marketing communication tools while purchasing the food products have been examined.

According to the consumer survey results; respondents were $60 \%$ male and $40 \%$ women. The average age of consumers was 33 and $42 \%$ had a high school diploma and only $20 \%$ had a university degree. Majority of consumers were $36 \%$ craftsmen/artisans while $18 \%$ housewives, $14 \%$ workers/employees, $13 \%$ qualified experts, $11 \%$ students and $5 \%$ unemployed or retired. The average family size is about 4 persons in the families participating in the survey. The average number of children per family is about 3 . The average income was $£ 1773$ and about one-third of the income devoted to food expenditures. Shopping for food was done mainly by mothers $(46.4 \%)$.

Consumers are the most affected by the price of the goods when they buy food and change the brand they use; however, they are the least affected by the advertisements as a tool. It is argued that customers base their purchasing decisions on what they already know about the product, not just on the remnants of an advertisement (Zavrsnik and Jerman. 2011). Roux and Zyl (2013) stated that more than $80 \%$ of consumers have positive attitudes towards sales promotional techniques and that less disposable income consumers are satisfied with the extra goods and low prices offered by the companies using sales promotion techniques. Yılmaz et al. (2007) reported that the vast majority (57\%) of the consumer group were affected by the advertisement and they decided to buy these food items accordingly. As a result of the research, it is seen that approximately $37 \%$ of the overall consumers is affected by advertisement therefore buys the product, thus it is to be said that advertisements as a marking tools are less effective than others. Although it has the rate of $29 \%$, regarding influencing the consumers to change brand already in use by the consumers advertisements are also less like to be influential compared to other kind of tools. It seems that sales promotions are more effective than other tools when a product purchase decision is made and the brand used is changed.

Any one of these characteristics - demographic (e.g., age, gender, race, etc.), psychographic (e.g. attitudes towards self, others, possessions, etc.), behavioural (e.g. brand choices, usage, loyalty, etc.) - may impact consumers' response to marketing communications Keller (2001). According to the research results, men affected more from the sales efforts than women. In this study, it was found that majority of men (63.01\%) influenced by advertisement while women were most influenced by price reduction. 
While changing the brands that they used, the tool that the men were most influenced were free trial $(61.03 \%)$, the tool that the women were most influenced were advantageous packages $(42.05 \%)$. Overall, consumers who purchased products least affected from sales efforts were consumers aged 45 and above. Yilmaz et al. (2007), found that young people with $41 \%$ is the group that is the most affected from the media. Our finding was also support this finding. When buying a certain product, younger consumers were also affected from other tools, which was advertisement. In changing of brand used, while young group were most affected from advertisement, other consumers were affected mainly from sale promotions. While literate, primary and secondary school graduates were influenced mostly by gifts buying a product, high school graduates were influenced by advertisement, college graduates were influenced by the price reductions. While products were being purchased, group who were the least influenced from sales efforts were literate people. Consumers who have different levels of education purchased products were influenced from different sales promotion techniques. While education level decreases, consumers seem to be affected more by tools such as gifts, free trials. The group who purchased products with the influence of marketing communication tools had income between $£ 1000$-1499. Consumers who had different income levels were affected from the different sales promotion techniques as well. Consumers with high income level were affected more from the ads when buying a particular product.

Drinks $(28.6 \%)$ and meat and meat products $(25.1 \%)$ were the product groups most affected by advertising. The product groups most affected by price discounts are milk and dairy products and meat and meat products. The most affected product groups are meat and meat products $(45.9 \%)$, beverages $(45.1 \%)$, fats $(43.6 \%)$. The most affected product groups are legumes $(53.4 \%)$, beverages $(52.6 \%)$, meat and meat products $(51.9 \%)$ and dairy products $(51.6 \%)$. Drinks $(46.6 \%)$ and meat and meat products $(43.4 \%)$ were the most affected by the products. Drinks (35.8\%) and meat and meat products (32.3\%) were the most affected by the awards, while the product groups that were most affected by the coupons were drinks (34.1\%). Yilmaz et al. (2007), consumers (chocolate, sugar and chips, $36.8 \%)$ were the second group (30.6\%) and drinks were the third group (10.8\%). Consumers often say that there is not a specific brand they prefer when buying general food, milk and dairy products, meat and meat products and fruit juices. However, $43.1 \%$ of the consumers who participated in the survey stated that milk and dairy products and $42.1 \%$ were a certain brand they always preferred when buying meat and meat products.

When we ask consumers to purchase general food, milk and dairy products, meat and meat products, and fruit juice from their purchasing points, it is seen that consumers mostly prefer to market in order to buy such products. When consumers buy these products, they prefer to market, reliability, complaints and suggestions are taken into consideration and the ease of return is in great effect. The consumers who participated in the research were mainly in the first sales area of products such as general food (45.4\%), dairy products $(43.1 \%)$, meat and meat products $(41.1 \%)$ and fruit juices $(40.9 \%$ is aware of it. Most of the product groups are meat and meat products and milk and dairy products. Fruit juices are mostly taken without any research.

While the price was the most important reason when buying the product for the first time for general food $(49.37 \%)$, meat and meat products $(20.55 \%)$, fruit juices $(18.55 \%)$ but the expiration date was important in milk and milk products $(22.81 \%)$.

Repurchase behaviour; as a result of the assessment that the consumer has done with respect to the past purchasing period, it is the decision to continue to buy the product and to become a regular user of it (Uçak, 2004). When the consumers who participate in the survey evaluated the most important reason why they buy the mentioned products for the second time; it was seen that their effect decreased proportionally although the price $(26.6 \%)$ is the most important reason in general food products. The expiry date $(21.3 \%)$ in milk and dairy products continues to be the most important reason, but the price is proportionally increasing in importance. While the price $(20.1 \%)$ in meat and meat products is the most important reason for buying for the second time, the importance of health compliance (14.3\%) decreases while the importance of the confidence (18\%) increases. While price $(17.8 \%)$ is the most important cause in fruit juices, proportionally the importance of trust (15.3\%) increases.

When consumers buy products, the level at which they make their purchasing decision is an important point. Decisions depend on advertisement, promotion and naturalness of the product were rated highly by consumers when it comes to milk and milk products. When buying the meat and meat products decisions were made mainly at the stores. When purchasing meat and meat products consumer were affected mainly by advertisement and promotions and the naturalness of the content was pointed out greatly important.

While consumer purchased different product groups, Chisquare test was conducted to see whether differences among attitudes toward marketing communications tools and among assessment of attitude against marketing communication tools according to product groups with consumer characteristics. There were differences among attitudes at 0.01 significance level ( $\mathrm{P}<0.01)$ while consumer purchased general foods, milk and dairy products, meat and meat products and juice. Consumers exhibited different attitudes toward marketing communication tools when buying different product groups. There are differences among attitudes at 0.01 significance level $(\mathrm{P}<0.01)$ while consumer purchased general foods, milk and dairy products, meat and meat products and juice according to gender, age, education level, occupation and income. Consumers who had different features demonstrated different attitudes against marketing communication tools when buying different product groups.

\section{Conclusion and Recommendations}

This study aims to investigate the effects of marketing communications tools, which businesses use for various purposes and are constantly exposed to in their consumers lives, on business performance and consumers' purchasing behaviour of food products. it has been determined that these tools have a significant effect on consumers' purchasing behaviour. In addition to the tools such as price, advantageous packages, free trial, gifts, prizes, packaging, 
advertising also has a significant effect on consumers' purchasing of food products. As a result, marketing communications tools used by businesses to advertise their products and sell them affect consumers' food purchasing behaviour. Although businesses resort to these tools as an expense element and in particular they apply to these tools in order to reduce inventories, consumers are affected by these tools and change the brand they use.

While these tools are effective on consumers, it is seen that they do not prefer to use tools such as public relations, sponsorship and fairs very much while they mainly use tools such as businesses, direct sales, sales promotions and personal sales. Taking into account the influence of these tools on the consumers, it is important for the companies to prefer the products to give them more space in product promotion and sales in order to provide competitive advantage, increase the market share and obtain high returns. However, businesses should use these tools in a more systematic and interdependent manner, which will provide greater benefits in increasing business performance. It is also stated that marketing communication tools have an impact on brand performance and market performance of enterprises and tools such as public relations and sponsorship are important in increasing customer satisfaction. Businesses need to use these tools more extensively in order to increase their commitment and loyalty, as well as other tools, of the customer to the business, the brand and the product. The difference between the attitudes of consumers' personal characteristics to their marketing communication tools is another issue that should be taken into account by businesses. Individuals with different characteristics are influenced by means of different communication and thus have an impact on purchasing behaviour. Businesses should focus on the use of communication tools that will influence them according to the shoppers by identifying who makes their food purchases in their families.

As a result of study, we can state that the enterprises are experiencing various problems. The participating enterprises cannot sell their products in the grocery store due to the shelf cost because they are large sized small enterprises. Given that consumers are predominantly making food purchases from grocery stores, it is not possible for a large volume of consumers to be aware of the products of small businesses, and it seems that these products do not have a chance to compete with the products of large businesses in markets. In order to enable small businesses to increase their chances of competition in the market and to prevent unfair competition in favour of small businesses, relevant institutions and organizations need to make legal arrangements in this regard.

Findings obtained in this study mainly include the opinions of small businesses operating in the food sector. In similar studies to be carried out after this, small enterprises are important for the repetition of such studies and for supporting the findings that larger studies and similar studies in different sectors are carried out. In addition, large enterprises operating in the food sector should conduct similar studies to investigate the use of marketing communications by large food establishments and assess whether BPI performance measures and brand and market performance relationships overlap with those in the literature.

\section{References}

Anantachart S. 2004. Integrated marketing communications and market planning: their implications to brand equity building. Journal of Promotion Management, 11 (1).

Babacan E, Kamanlığlu EB, Alemdar MY. 2008. The usage of internet in marketing communications and public relations activities: A research on travel agencies in Izmir, İstanbul Üniversitesi İletişim Fakültesi Dergisi, 32(1): 5-24.

Çalık M; Altunışık R; Sütütemiz N. 2013. An investigation of the relationship among integrated marketing communication (imc), brand performance and market performance. Int. Journal of Management Economics and Business, 9(19): 137-162.

Duncan T, Moriarty SE. 1998. A communication-based marketing model for managing relationships. Journal of Marketing, 62: 1-13.

Durmaz M. 2001. About the marketing communication. İstanbul Üniversitesi İletişim Fakültesi Dergisi, 11(1): 237-241.

Ebren F. 2006. Bütünleşik pazarlama iletişiminin algılanışı ve uygulanması: reklam ajansları ve firmalar düzeyinde araştırmalar. Doktora Tezi, Akdeniz Üniversitesi Sosyal Bilimler Enstitüsü İşletme Anabilim Dalı, Antalya.

Erpelit İ. 2010. Marka imajı oluşturulmasında bütünleşik pazarlama iletişimi ve halkla ilişkilerin rolü. Yüksek Lisans Tezi, Ege Üniversitesi Sosyal Bilimler Enstitüsü Halkla İlişkiler ve Tanıtım Anabilim Dalı, İzmir.

Esposito A. 2013. Insights about integrated marketing communication in small-and-medium-sized Italian enterprises. Business Systems Review, Volume 2- Issue 1, ISSN: 2280-3866, DOI: http://dx.medra.org /10.7350/BSR.B08.2013.

GTHB. 2014. Üretim izinli firma listesi, Adana ve Mersin İl Gida Tarım ve Hayvancılık Müdürlüğü, Gıda Tarım ve Hayvancılık Bakanlığı, Ankara.

İçli G. 2010. Analyzing marketing communication means according to the Turkish wine sector. Marmara Üniversitesi Sosyal Bilimler Dergisi, 127-133.

Jerman D, Zavrsnik B. 2013. Can marketing communications affect consumer behaviour? Economics Management Information Technology, 1(4).

Keller KL. 2009. Building strong brands in a modern marketing communications environment. Journal of Marketing Communications, 15:2-3, 139-155, DOI: $10.1080 / 13527260902757530$.

Keller KL. 2001. Mastering the marketing communications mix: micro and macro perspectives on integrated marketing communication programs. Journal of Marketing Management, $\quad 17: 7-8, \quad 819-847, \quad$ DOI: 10.1362/026725701323366836.

Korkut Öİ, Akyol A, Altaş D. 2005. The role of the integrated marketing communications' on creating brand equity and its effects on the company performance: an empirical reserach on bevarage sector. Trakya Üniversitesi Sosyal Bilimler Dergisi, 2(7): 13-32.

Mihart (Kailani) C. 2012. Impact of integrated marketing communication on consumer behaviour: effects on consumer decision-making process, International Journal of Marketing Studies, 4(2).

Mutlu S. 2007. Gıda güvenirliği açısından tüketici davranışları (Adana kentsel kesimde kırmızı et tüketimi örneği). Çukurova Üniversitesi Fen Bilimleri Enstitüsü Tarım Ekonomisi Anabilim Dalı Doktora Tezi, Adana.

Odabaşı Y, Oyman M. 2012. Pazarlama İletişimi Yönetimi. Mediacat Yayınları, 11. Baskı, İstanbul.

Odunlamı IB, Ofoegbu OE. 2011. Effect of marketing communication in promoting organizational sales: a case study of sunshine company. Journal of Emerging Trends in Economics and Management Sciences (JETEMS) 2 (5): 408412, Scholarlink Research Institute Journals, (ISSN: 21417024), jetems.scholarlinkresearch.org. 
Özgül N. 2008. Bütünleşik pazarlama iletişiminde gerilla pazarlama stratejilerinin kullanılması. Ege Üniversitesi Sosyal Bilimler Enstitüsü Halkla İlișkiler ve Tanıtım Anabilim Dalı, Yüksek Lisans Tezi, İzmir.

Reid M. 2005. Performance auditing of integrated marketing communication (IMC) actions and outcomes. Journal of Advertising, 34(4): 41-54.

Reid M, Johnson T, Ratcliffe M, Skrip K, Wilson J. 2001. Integrated marketing communication in the Australian and New Zealand wine industry. International Journal of Advertising, 20, 239-262.

Roux T, Zyl D. 2013. The effects of sales promotion techiques on consumers' behaviour: A South African perspective. http://marketing.conference-services.net /resources/327/3554/pdf/AM2013_0383_paper.pdf, (Erişim: 26.10.2013).
Tuğrul MS. 2009. Müşteri sadakati sağlamada bir pazarlama iletişimi aracı olarak müşteri ilişkileri yönetimi ve algılanışı üzerine bir araştırma. Marmara Üniversitesi Sosyal Bilimler Enstitüsü İletişim Bilimleri Anabilim Dalı Bilişim Bilim Dalı, Yüksek Lisans Tezi, İstanbul.

Uçak P. 2004. Pazarlama iletişimi aracı olarak reklamın tüketici davranışlarına etkisi. Ankara Üniversitesi Sosyal Bilimler Enstitüsü Halkla İlişkiler ve Tanıtım Anabilim Dalı, Yüksek Lisans Tezi, Ankara.

Yılmaz E, Yılmaz İ, Uran H. 2007. Gıda maddeleri tüketiminde medyanın rolü: Tekirdağ ili örneği. Gıda Teknolojileri Elektronik Dergisi, 3 3: 9-14, www.teknolojikarastirmalar.com, ISSN: 1306-7648.

Zavrsnik B, Jerman D. 2011. Measuring integrated marketing communication. Scientific Annals of the Alexandru Ioan Cuza University of Iasi: Economic Sciences Series, LVIII: 351-362 